\title{
Laboratory Efficacy and Disinfection by-Product Formation of a Coagulant/Disinfectant Tablet for Point-of-Use Water Treatment
}

\author{
Félix Légaré-Julien ${ }^{1}$, Olivier Lemay ${ }^{1}$, Ulysse Vallée-Godbout ${ }^{1}$, Christian Bouchard $^{1}$ and \\ Caetano C. Dorea $1,2,3, *$ (D) \\ 1 Département de génie civil et génie des eaux, Université Laval, Québec, QC G1V 0A6, Canada; \\ felix.legare-julien@mddelcc.gouv.qc.ca (F.L.-J.); olivier.lemay.1@ulaval.ca (O.L.); \\ ulysse.vallee-godbout.1@ulaval.ca (U.V.-G.); christian.bouchard@gci.ulaval.ca (C.B.) \\ 2 Department of Civil Engineering, University of Victoria, Victoria, BC V8P 5C2, Canada \\ 3 Environment \& Regional Development Graduate Program (PGDRA), Universidade Federal de \\ Rondônia (UNIR), Porto Velho, Rondônia 76815-800, Brazil \\ * Correspondence: caetanodorea@uvic.ca; Tel.: +1-250-472-5844
}

Received: 26 September 2018; Accepted: 1 November 2018; Published: 2 November 2018

\begin{abstract}
Coagulant/disinfection products (CDPs) are a point-of-use (POU) water treatment technique that can improve microbial quality, reduce turbidity, and produce a free chlorine residual (FCR), serving as a potentially effective option for decentralized water treatment in a variety of contexts, including humanitarian emergencies. A novel CDP with a sodium dichloroisocyanurate-based disinfectant was evaluated with regard to its laboratory water treatment efficacy and generation of disinfection byproducts (DBPs). The CDP water treatment performance was assessed relative to bacteriological (E. coli) humanitarian water quality objectives, World Health Organization recommendations for evaluating POU water treatment options, and available DBP regulations and guidelines. At least $4 \log _{10}$ E. coli reductions, for a "highly protective" status with regard to bacterial reductions, were attained in the tested conditions. Treated waters were consistently below $10 \mathrm{MPN} / 100 \mathrm{~mL}$ with regard to $E$. coli concentrations, with the majority of samples showing no detectable E. coli. For most conditions, target FCR values were not attained. Treated water turbidity levels were mostly between 5 NTU and 10 NTU. DBP levels were below the regulatory and health-based targets for both families of DBPs studied. This study has served to identify the performance envelopes of the CDP tested under challenging conditions.
\end{abstract}

Keywords: coagulation; decentralized; disinfection by-products; emergency water treatment; flocculation; household; NaDCC; point-of-use

\section{Introduction}

Point-of-use (POU) water treatment can improve microbial water quality and decrease diarrhoeal disease incidence in development contexts [1]. Such techniques could reduce the risk of waterborne disease transmission for the estimated 0.8 to 1.8 billion people who lack access to safe drinking water [2]. Some studies indicate a potential for similar effectiveness water quality improvements in humanitarian emergencies [3,4], where affected populations may be more vulnerable.

Coagulant/disinfection products (CDPs) are unique relative to other available POU techniques (e.g., boiling, household chlorination, ceramic filtration, etc.) because of their capacity to achieve microbial quality improvement, turbidity reductions, and a post-treatment free chlorine residual (FCR). CDPs utilize conventional drinking water treatment processes (i.e., coagulation, flocculation, sedimentation, filtration, and disinfection) in a simplified (reduced/household) batch scale. Use of 
such products has been studied for both development [5,6] and humanitarian relief [7-9] applications. Typically, CDPs are available as sachets containing two main active ingredients (i.e., a coagulant and a disinfectant) in powdered form. It has been hypothesized that the lower chlorine demand (partially due to the simultaneous addition of a coagulant) and the physical removal of some chlorine-resistant organisms (i.e., by sedimentation and filtration) may provide a health advantage over chlorination alone [5].

Most CDPs (e.g., Bishan Gari, P\&G Purifier of Water, etc.) rely on calcium hypochlorite as the disinfectant. Clasen and Edmondson [10] have contended that the differentiated chemistry of sodium dichloroisocyanurate $(\mathrm{NaDCC})$ is thought to be comparatively advantageous over calcium hypochlorite in contexts where water can have high or variable chlorine demands. Although NaDCC also uses hypochlorite as the active disinfectant, only $50 \%$ of its chlorine is released, and the remainder is kept as "reservoir chlorine" (bound chlorinated isocyanurates) gradually releasing further chlorine [10]. Therefore, a NaDCC-based CDP could have a relative advantage over similar products by providing a longer-lasting protective chlorine residual.

According to Lantagne et al. [11,12], some health authorities and implementing agencies have expressed concern over the formation of unwanted disinfection by-products (DBPs) when using NaDCC as a POU disinfectant. In general, there has been little peer-reviewed research devoted to the characterization of DBP formation during POU water treatment [11-14], whereas two studies included the use of CDP [11,12], they were limited to trihalomethanes (THMs), and did not include haloacetic acids (HAAs), another family of DBPs of concern.

Laboratory efficacy testing can serve to highlight the performance envelopes of this type of POU water treatment product $[9,15]$. This type of testing can also serve to highlight other relevant issues such as the product's capability of maintaining adequate FCR levels and can indicate possible levels of DBPs that could be generated by its use. The objective of this study was to evaluate the laboratory treatment efficacy and generation of DBPs (THMs and HAAs) of a CDP with a NaDCC disinfectant under challenging conditions.

\section{Materials and Methods}

\subsection{Product Description}

The AQS $10 \mathrm{~L}$ is a CDP manufactured by Aquasure S.A.S. (St Just St Ramber, France) in the form of a double-layered tablet containing ferric sulfate (an active coagulant) and NaDCC (a disinfectant). According to the manufacturer, these chemicals allow for treatment in a "sequenced double action" by the initial dissolution of the coagulant followed by a slow release of the disinfectant. Although the specific proprietary formulation is not known, the AQS $10 \mathrm{~L}$ (referred to simply as AQS hereafter) tablets, according to the manufacturer, are also said to contain two unnamed anionic polymers as flocculants. At the time of testing, the AQS tablets were still at an experimental stage and not yet commercialized. A version of the product was available at the time of writing. Each tablet is designed to treat $10 \mathrm{~L}$ of water. Its usage follows similar steps to other CDPs (albeit with a slightly longer settling period) consisting of manual stirring $(5 \mathrm{~min})$, settling $(55 \mathrm{~min})$, and cloth filtration (totaling a treatment time of $60 \mathrm{~min}$ ). For cold temperatures, the manufacturer recommended the same dosage, but with a settling period of $115 \mathrm{~min}$ (totaling a treatment time of $120 \mathrm{~min}$ ).

\subsection{Experimental Setup}

The AQS tablets were tested in sterile polypropylene buckets ( $10 \mathrm{~L}$ test volume). A Kemwater Flocculator 2000 (Kemira, Helsingborg, Sweden) stirring paddle provided uniform mixing for the prescribed time. A J-Cloth (Associated Brands, Mississauga, ON, Canada) was used as the filtration material as it was relatively thin ( 2 to $3 \mathrm{~mm}$ ) and porous. This was also in line with the adopted testing approach of evaluating the $\mathrm{CDP}^{\prime} \mathrm{s}$ performance under challenging conditions (relative to 
coagulation and disinfection) and has been adopted in previous studies on POU water treatment product evaluations $[9,15]$.

\subsection{CDP Evaluation}

Treatment performance of the AQS tablet was evaluated against established water quality guidelines [16] and humanitarian [17] water treatment objectives: Non detectable Escherichia coli per $100 \mathrm{~mL}$, turbidity less than 5 nephelometric turbidity units (NTU), and a FCR of at least $0.5 \mathrm{mg} / \mathrm{L}$ (after a minimum 30 min contact time and $\mathrm{pH}<8$ ). Bacterial $\log _{10}$ reductions (LRs) were assessed with regards to WHO [18] guidelines for the evaluation of POU treatment products. This part of the study was conducted between January and April 2014 with an initial batch of AQS tablets supplied by the manufacturer.

The product's capacity to keep a target FCR level of at least $0.2 \mathrm{mg} / \mathrm{L}$ after $24 \mathrm{~h}[19,20]$ was also assessed in simulated storage tests. This was done under varied initial water quality conditions designed to challenge the product with regard to its underpinning treatment processes (i.e., coagulation and disinfection). Tests on each water condition were repeated three times for statistical robustness.

Separate testing characterized the DBP formation in August 2015 with a new batch of tablets supplied by the manufacturer. Two families of DBPs were evaluated, consisting of four THMs (chloroform (TCM), bromodichloromethane (BDCM), dibromochloromethane (DBCM) and tribromomethane (TBM)) and five HAAs (monochloroacetic acid (MCAA), monobromoacetic acid (MBAA), dichloroacetic acid (DCAA), trichloroacetic acid (TCAA) and dibromoacetic acid (DBAA)). The sums (on a mass basis) of these four THMs and five HAAs were evaluated against USEPA [21] maximum contaminant limits of $0.080 \mathrm{mg} / \mathrm{L}$ and $0.060 \mathrm{mg} / \mathrm{L}$, respectively.

\subsection{Treatment Performance Trials}

Treatment performance trials took into consideration previous testing of CDPs $[9,15]$ that demonstrated that alkaline $\mathrm{pH}$ and cold temperatures are of particular interest to challenge the microbiological efficacy of CDPs (i.e., test series A, B, and C). Such conditions were shown to affect chlorination efficiency. Furthermore, acidic $\mathrm{pH}$ and high turbidity were also identified as being of interest for the evaluation of turbidity reductions (i.e., test series A, D, and E) due to their effect on other underpinning treatment processes (i.e., coagulation, sedimentation, and filtration). These tests were performed on a test water matrix based on a primary settled wastewater (PSW) dilution (i.e., test series A-E) as well as on natural surface waters described below (i.e., test series F and G).

\subsection{Simulated Storage FCR Experiments}

Additional tests were aimed at assessing the protective FCR profiles under simulated storage conditions, as used in previous product evaluations $[9,22]$. The AQS tablet was used as per product instructions and $1 \mathrm{~L}$ aliquots of treated water were collected in $1000 \mathrm{~mL}$ polypropylene bottles that had their caps fitted, but not tightened, and stored at ambient room temperature. FCR was determined at 1, 2, 4, and $24 \mathrm{~h}$ following the addition of the product to the test water. Evaluation of FCR levels in simulated storage tests was conducted in both natural (test series F and G) and synthetic (i.e., test series $\mathrm{H}$ and I) test waters.

\subsection{Disinfection by-Product Formation Tests}

DBP formation tests were performed separately and in a similar fashion to other tests as per product instructions, using natural surface waters (test series J and K) and on synthetic water (test series L). $1000 \mathrm{~mL}$ aliquots of treated water were collected in polypropylene bottles, as in the simulated storage FCR experiments, and stored in an incubator set at $20^{\circ} \mathrm{C}$. THMs, HAAs, pH, and FCR were sampled at 2 and $24 \mathrm{~h}$ after treatment. 


\subsection{Test Waters}

Different types of test waters were used in this study: Primary settled wastewater dilution (PSWd), distilled water (DW), distilled water with humic acid (DW-HA), surface water high in organics (SW-High), and surface water low in organics (SW-Low). These are further described below and summarised in Table 1 with the corresponding test series.

A 1:5 dilution (in dechlorinated tap water) of a primary settled wastewater from a local wastewater treatment plant was used as the test water (PSWd) for test series A to E. This was in line with the WHO [18] POU water treatment evaluation recommendations, simulating a grossly polluted drinking-water source. PSW samples were collected on a weekly basis and stored in a cold room $\left(<4{ }^{\circ} \mathrm{C}\right)$ until use and had an average chemical oxygen demand of $116.8 \mathrm{mg} / \mathrm{L}$, a suspended solids concentration of $45.4 \mathrm{mg} / \mathrm{L}$, and a turbidity of $44.2 \mathrm{NTU}$, as reported previously [9]. Test water quality was adjusted according to desired initial conditions (i.e., turbidity, $\mathrm{pH}$, and temperature). Turbidity was adjusted using a kaolin clay (Sigma-Aldrich, St. Louis, MO, USA) to $\pm 10 \%$ of the target turbidity. The $\mathrm{pH}$ was modified using solutions of either $\mathrm{H}_{2} \mathrm{SO}_{4}$ or $\mathrm{NaOH}$ to 5.0, 7.0 or 9.0. A crushed ice jacket around the $10 \mathrm{~L}$ vessel kept the test water at $5 \pm 1{ }^{\circ} \mathrm{C}$ for cold temperature trials, as it was shown previously that cold temperatures can affect CDP performance [15]. All other trials were conducted at a target temperature of $20^{\circ} \mathrm{C}$ (in ambient conditions).

Table 1. Summary of test series and corresponding (adjusted) target test water characteristics.

\begin{tabular}{cccccc}
\hline $\begin{array}{c}\text { Test } \\
\text { Series }\end{array}$ & $\begin{array}{c}\text { Testing } \\
\text { Objective }\end{array}$ & $\begin{array}{c}\text { Turb. } \\
\text { (NTU) }\end{array}$ & pH & $\begin{array}{c}\text { Temp. } \\
\left({ }^{\circ} \mathbf{C}\right)\end{array}$ & Test Water Matrix \\
\hline A & Treatment & 100 & 7.0 & 20 & PSWd-PSW dilution \\
B & Treatment & 100 & 9.0 & 20 & PSWd-PSW dilution \\
C & Treatment & 100 & 5.0 & 20 & PSWd-PSW dilution \\
D & Treatment & 100 & 7.0 & 5 & PSWd-PSW dilution \\
E & Treatment & 800 & 7.0 & 20 & PSWd-PSW dilution \\
F & Treatment/FCR & - & - & 20 & SW-Low-St. Lawrence River \\
G & Treatment/FCR & - & - & 20 & SW-High1-Chaudière River \\
H & FCR & - & - & 20 & DW-Distilled water \\
I & FCR & - & - & 20 & DW+HA1-Distilled water + 30 mg/L HA \\
J & DBP & - & - & 20 & SW-Low-St. Lawrence River \\
K & DBP & - & - & 20 & SW-High2-Marais du Nord \\
L & DBP & - & - & 20 & DW+HA2-Distilled water + 11.5 mg/L HA \\
\hline
\end{tabular}

AQS was tested (treatment performance and simulated storage trials) on natural surface waters (i.e., test series $\mathrm{F}$ and $\mathrm{G}$ ) with average total organic carbon (TOC) contents that were relatively high (SW-High1: Chaudière River-averaging $8 \mathrm{mg} / \mathrm{L}$ ) and low (SW-Low: Saint Lawrence River-averaging $4 \mathrm{mg} / \mathrm{L}$ ). It was thought that these would be more representative of field use conditions than the synthetic PSWd test water used to characterise the product's performance envelope with regards to different chlorine demands. As treatment performance trials were conducted between January and April 2014, a slight modification was made with regard to the natural surface water source used for series $\mathrm{G}$ in comparison to previous studies on CDPs. The source used previously [9] to represent a natural surface water high in organics (i.e., Marais du Nord) was completely frozen at the time of performance testing, and thus was unavailable for treatment performance trials. SW-High1 and SW-Low samples were collected from local drinking water treatment plants and stored in a cold room $\left(<4{ }^{\circ} \mathrm{C}\right)$ until use (within a week) and brought to room temperature and homogenized before each test. DBP formation tests on natural surface waters were also conducted with natural waters with TOC levels that were relatively high (SW-High2: Marais du Nord—averaging $11 \mathrm{mg} / \mathrm{L}$ ) and low (SW-Low: Saint Lawrence River-averaging $4 \mathrm{mg} / \mathrm{L}$ ).

Synthetic test waters (i.e., DW and DW-HA) were used in simulated storage tests (test series $\mathrm{H}$ and I) and in DBP formation tests. DW was the chlorine demand free water used to assess the maximum FCR attainable. Humic acid (Sigma-Aldrich) was added to DW to benchmark CDP performance if future comparisons with other products are envisioned. It was added at a concentration of $30 \mathrm{mg} / \mathrm{L}$ to 
make up DW-HA1 to be used in the simulated storage tests. A second synthetic test water (DW-HA2) was prepared for DBP formation tests by adding humic acid (11.5 mg/L) to DW, corresponding to a water with relatively low TOC that would still result in a $24 \mathrm{~h}$ FCR [23]. These synthetic test waters were prepared daily and could serve for benchmarking purposes between products.

\subsection{Analytical Methods}

Turbidity, $\mathrm{pH}$, and FCRs were measured in duplicates using a $2100 \mathrm{P}$ turbidimeter, HQ40d pH meter, and Pocket Colorimeter ${ }^{\mathrm{TM}}$, respectively, as specified by the manufacturer $(\mathrm{HACH}, \mathrm{Loveland}, \mathrm{CO}$, USA). Triplicate enumeration of naturally occurring E. coli in the PSWd and natural test waters was performed with the Colilert Quanti-tray/2000 system (IDEXX Laboratories, Markham, ON, Canada). A detailed description of the THM and HAA analyses are available elsewhere [24].

\subsection{Statistical Analysis}

An analysis of variance (ANOVA) was used to compare bacterial LRs and turbidity reductions. Where significant differences were noted, post-hoc analyses using Dunnett's test were performed. To this end, Series A (i.e., $100 \mathrm{NTU}, \mathrm{pH} 7$, and $20^{\circ} \mathrm{C}$ ) was defined as the "reference" (i.e., control) test water condition for comparisons between treatment series using the same test water matrix. Geometric means were used for microbiological data, whereas arithmetic means were used for all other parameters. A value of $0.5 \mathrm{MPN} / 100 \mathrm{~mL}$ was used for the calculation of bacterial geometric means and LRs with regards to non-detects (i.e., $<1 \mathrm{MPN} / 100 \mathrm{~mL}$ ). Statistically significant differences were defined at a significance level of $\alpha=0.05$.

\section{Results}

\subsection{Bacterial Reductions}

Overall, mean treated water E. coli concentration was of $1.2 \times 10^{0}\left(95 \%\right.$ CI $\left.0.3-1.2 \times 10^{1}\right) \mathrm{MPN} /$ $100 \mathrm{~mL}$ (Table 2), with 70\% of the samples below the detection limit of $1 \mathrm{MPN} / 100 \mathrm{~mL}$. Average LRs of the different conditions tested varied between 2.1 and 5.3 (Figure 1). Overall average bacterial LRs for the PSWd test water matrix (Series A to E) and natural surface waters (Series F and G) were 5.1 and 2.5, respectively. There was no statistically significant difference $(p=0.16)$ between LRs of the PSWd test series A-E (i.e., no effect from $\mathrm{pH}$ or temperature). Some mean treated water bacterial concentrations were less than the E. coli quantification detection limit of $1 \mathrm{MPN} / 100 \mathrm{~mL}$. Some LR values could be expected to be higher as they were censored by the initial bacterial concentrations in both synthetic and natural test waters (Series C, E, F, and G) that ranged from $2.6 \times 10^{2}\left(95 \%\right.$ CI $\left.0.9-8.7 \times 10^{2}\right)$ to $1.7 \times 10^{5}\left(95 \%\right.$ CI 1.1-5.2 $\left.\times 10^{4}\right) \mathrm{MPN} / 100 \mathrm{~mL}$. In such cases, the reported means were conservative with respect to microbial reductions.

Table 2. Summary of the AQS treatment performance trials mean microbiological results (with $95 \%$ confidence intervals) for initial (untreated) and final (after Coagulant/disinfection product (CDP) treatment-60 $\mathrm{min}$ for all test conditions except "cold temperature" series D in which treatment time totaled $20 \mathrm{~min}$ ) waters.

\begin{tabular}{cccc}
\hline Series & $\begin{array}{c}\text { Test } \\
\text { Water Matrix }\end{array}$ & Initial & E. coli (MPN/100 mL) \\
A & PSWd & $3.1 \times 10^{5}(1.9$ to 5.2$) \times 10^{5}$ & $6.6 \times 10^{0}(4.5$ to 33.1$) \times 10^{0}$ \\
B & PSWd & $2.4 \times 10^{5}(1.9$ to 3.0$) \times 10^{5}$ & $2.7 \times 10^{0}(<1$ to 54.3$) \times 10^{0}$ \\
C & PSWd & $1.7 \times 10^{5}(1.1$ to 5.2$) \times 10^{5}$ & $<1 \times 10^{0}(<1$ to $<1) \times 10^{0}$ \\
D & PSWd & $1.1 \times 10^{5}(0.7$ to 2.0$) \times 10^{5}$ & $1.1 \times 10^{0}(<1$ to 4.8$) \times 10^{0}$ \\
E & PSWd & $1.5 \times 10^{5}(1.1$ to 3.2$) \times 10^{5}$ & $<1 \times 10^{0}(<1$ to 1.3$) \times 10^{0}$ \\
F & SW-Low & $2.6 \times 10^{2}(0.9$ to 7.9$) \times 10^{2}$ & $<1 \times 10^{0}(<1$ to $<1) \times 10^{0}$ \\
G & SW-High1 & $2.7 \times 10^{2}(1.9$ to 4.0$) \times 10^{2}$ & $<1 \times 10^{0}(<1$ to 3.9$) \times 10^{0}$ \\
\hline
\end{tabular}




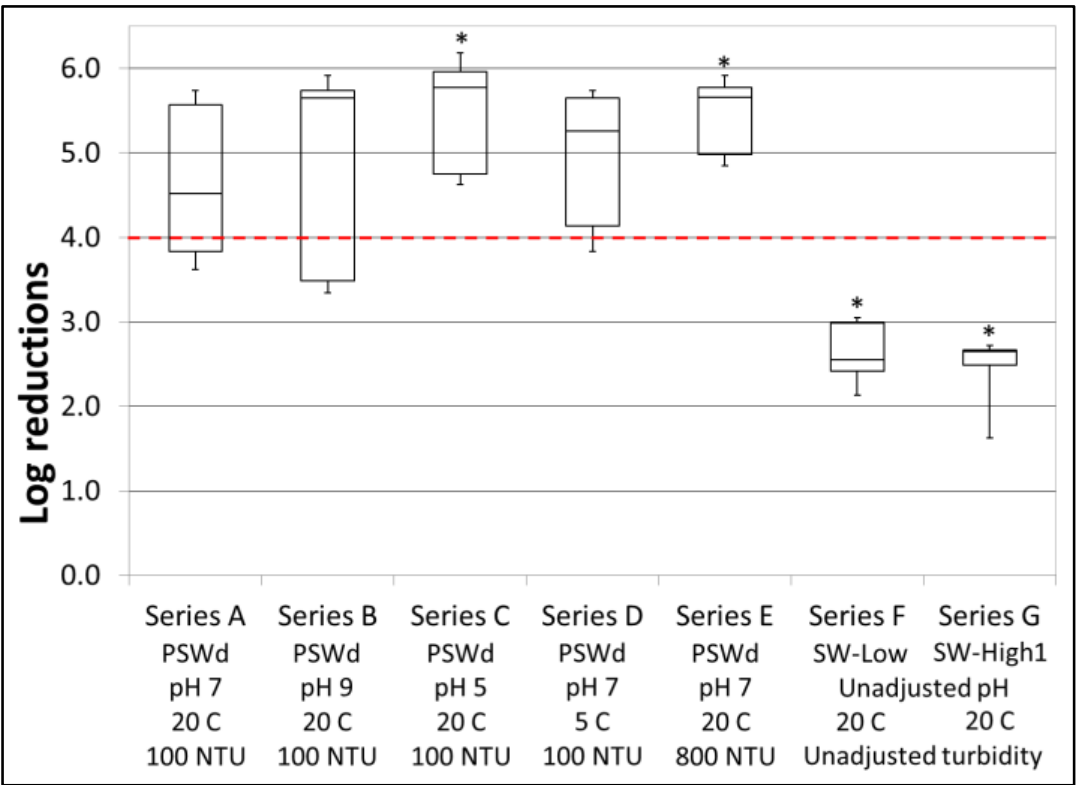

Figure 1. Box-and-whisker plots ( $\mathrm{min} / \mathrm{max}$, lower/upper quartiles, and median) of average E. coli $\log 10$ reductions (LRs) with AQS treatment with different test waters and conditions. The asterisk ${ }^{*}$ ) indicates that the mean bacterial concentration after treatment is below the limit of detection. The dashed line represents the LR default value to be considered "highly protective" with regard to bacterial removal/inactivation, as defined by the WHO [18].

\subsection{Turbidity Reductions}

The average treated water turbidity was of 7.8 NTU with $14 \%$ of samples below the target treated water turbidity of 5 NTU. Average turbidity reduction efficiencies were between the required reductions to achieve final turbidity levels close to 5-10 NTU, except for natural surface water test series $F$ and $G$, where the treated water turbidity was greater than that of the untreated waters (Table 3). Treated water turbidity levels were not significantly different $(p=0.28)$ between the different conditions tested (i.e., test series $A-G)$.

Table 3. Summary of AQS treatment performance trials mean physico-chemical results (with \pm standard deviations) for initial (untreated) and final (after CDP treatment-60 min for all test conditions except "cold temperature" series D in which treatment time totaled $20 \mathrm{~min}$ ) waters.

\begin{tabular}{cccccccc}
\hline \multirow{2}{*}{ Series } & Test & \multicolumn{2}{c}{ Turbidity (NTU) } & FCR $(\mathbf{m g} / \mathbf{L})$ & \multicolumn{2}{c}{ pH } & \multicolumn{2}{c}{ Temp. $\left({ }^{\circ} \mathbf{C}\right)$} \\
& Water Matrix & Initial & Final & Final & Initial & Final & Final \\
\hline A & PSWd & $96 \pm 2$ & $5.1 \pm 0.7$ & $0.08 \pm 0.04$ & $7.0 \pm 0.1$ & $6.2 \pm 0.1$ & $19.2 \pm 2.0$ \\
B & PSWd & $97 \pm 2$ & $7.9 \pm 2.8$ & $0.08 \pm 0.02$ & $9.0 \pm 0.0$ & $7.1 \pm 0.2$ & $19.2 \pm 1.7$ \\
C & PSWd & $98 \pm 7$ & $6.4 \pm 0.4$ & $0.05 \pm 0.01$ & $5.0 \pm 0.0$ & $5.0 \pm 0.1$ & $18.1 \pm 0.6$ \\
D & PSWd & $101 \pm 5$ & $5.3 \pm 0.9$ & $0.05 \pm 0.01$ & $7.0 \pm 0.0$ & $6.1 \pm 0.1$ & $5.6 \pm 0.2$ \\
E & PSWd & $764 \pm 27$ & $11 \pm 6$ & $0.07 \pm 0.01$ & $7.0 \pm 0.1$ & $6.3 \pm 0.2$ & $18.2 \pm 0.3$ \\
F & SW-Low & $4.8 \pm 0.7$ & $7.4 \pm 4.8$ & $0.54 \pm 0.52$ & $7.1 \pm 0.1$ & $6.1 \pm 0.1$ & $18.7 \pm 1.6$ \\
G & SW-High1 & $3.9 \pm 3.2$ & $12 \pm 5$ & $0.03 \pm 0.01$ & $6.7 \pm 0.2$ & $6.0 \pm 0.2$ & $18.8 \pm 1.5$ \\
\hline
\end{tabular}

\subsection{Free Chlorine Residuals}

The average FCR level after treatment (60 min after initial dosing) with AQS was of $0.16 \mathrm{mg} / \mathrm{L}$, with average FCR levels for PSWd and natural surface waters of $0.06 \mathrm{mg} / \mathrm{L}$ and $0.28 \mathrm{mg} / \mathrm{L}$ (Table 3), respectively. 5\% of samples from the treatment performance trials achieved the minimum recommended FCR level of $0.5 \mathrm{mg} / \mathrm{L}$ by the end of the prescribed treatment time. During simulated storage tests (Figure 2), target FCR levels (i.e., $0.5 \mathrm{mg} / \mathrm{L}$ after prescribed treatment time) were only 
observed in the SW-Low and DW test waters (test series F and H, respectively). The target $24 \mathrm{~h} \mathrm{FCR}$ concentration of at least $0.2 \mathrm{mg} / \mathrm{L}$ was only achieved with the demand free DW test water.

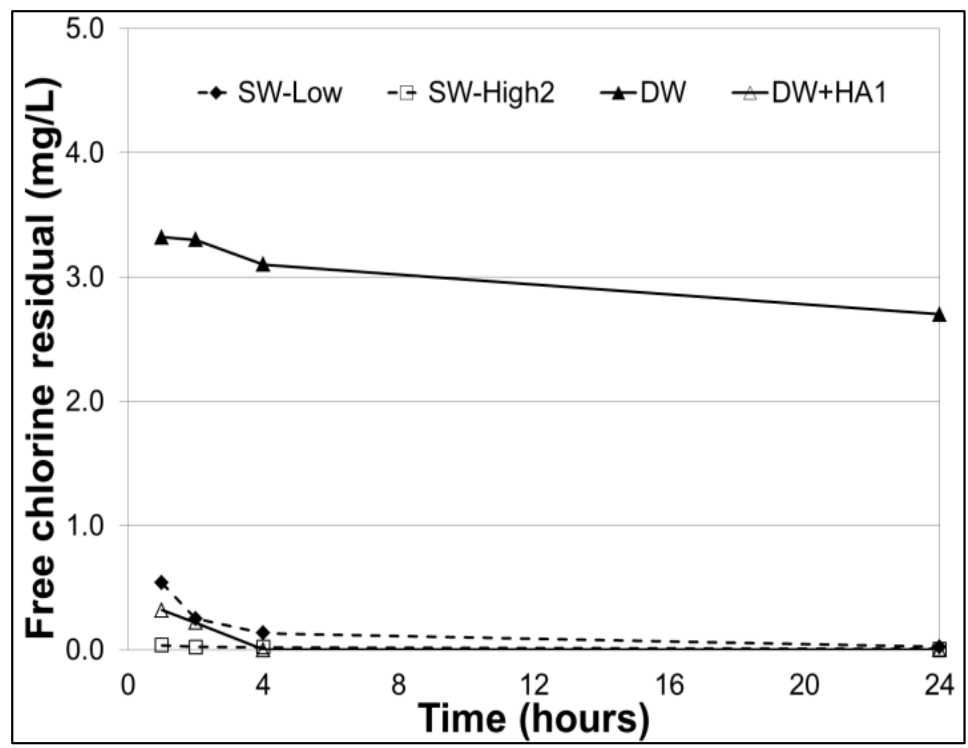

Figure 2. Simulated $24 \mathrm{~h}$ storage tests free chlorine residual trends.

\subsection{Disinfection Byproducts}

Results for the DBP trials are presented in Figure 3. Average total THMs were 0.018 and $0.042 \mathrm{mg} / \mathrm{L}$ at 2 and $24 \mathrm{~h}$, respectively, following treatment. Only two of the four THM species analyzed were detected, and speciation consisted primarily of TCM. For total HAAs, averages were of 0.029 and $0.052 \mathrm{mg} / \mathrm{L}$ at 2 and $24 \mathrm{~h}$, respectively, following treatment. Four of the five HAAs that were analyzed were detected with TCAA and DCAA forming the majority of the total HAA measured.

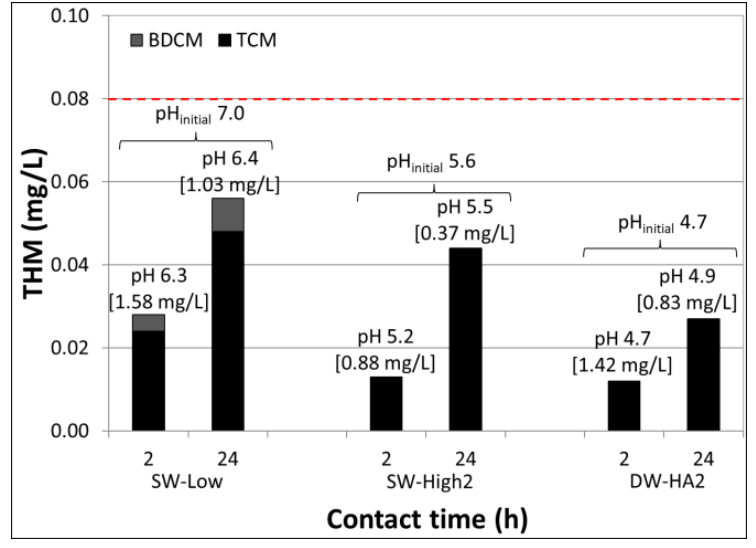

(a)

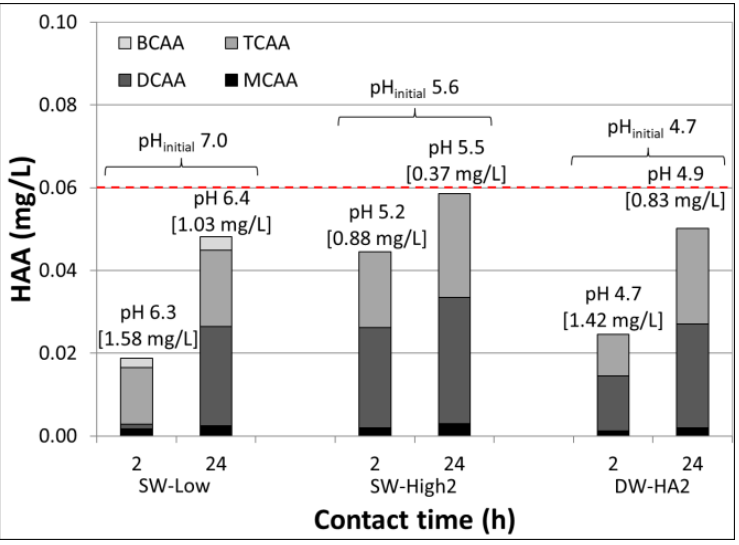

(b)

Figure 3. Total trihalomethane (THM) (a) and haloacetic acid (HAA) (b) formation at 2 and $24 \mathrm{~h}$ after treatment with AQS alongside $\mathrm{pH}$ and free chlorine residual (FCR) (in square brackets) at different sampling times. Dashed lines represent USEPA [21] maximum contaminant limits of $0.080 \mathrm{mg} / \mathrm{L}$ and $0.060 \mathrm{mg} / \mathrm{L}$ for THMs and HAAs, respectively.

\section{Discussion}

The CDP achieved bacterial LRs greater than 4 for test series A-E, which is the minimum default value to be considered a "highly protective" POU treatment option, as defined by the WHO [18]. Test series F and G did not allow for such an assessment to be made, as the attained bacterial LRs were censored by the relatively lower initial E. coli concentrations of the natural surface waters that were 
tested. Test series at initial $\mathrm{pH} 9$ and at cold temperatures $\left(<5^{\circ} \mathrm{C}\right)$ did not yield LRs with differences from the reference condition that were statistically significant, as observed with other CDPs tested in similar conditions $[9,15]$. In general (except in series $\mathrm{C}-\mathrm{pH} 5$ test water), finished water $\mathrm{pH}$ was typically lower than initial target $\mathrm{pH}$. This slight $\mathrm{pH}$ drop is thought to have occurred due to ferric sulfate alkalinity consumption. Finished water $\mathrm{pH}$ in alkaline test water conditions was below 8 (Figure 4), above which hypochlorite ion speciation (a less effective disinfectant) is favored. This is indicative of sufficient buffering capacity of the tested CDP for alkaline conditions where it is perhaps most needed. Tests at cold temperatures had longer prescribed disinfectant contact times, which are thought to have overcome the cold temperature effects on disinfectant efficiency. Otherwise, LRs observed in this study were similar to other such studies and are consistent with findings of other laboratory evaluations [25-27]. Notably, the relatively low FCR values observed (i.e., some close the method detection limit of $0.02 \mathrm{mg} / \mathrm{L}$-Table 3) in most trials may signify that bacterial LRs could have been higher if a stronger FCR concentration was present. The overall protective capacity of the AQS tablets could not be assessed, as viral and protozoan indicators were not tested for. According to the bacteriological water quality risk categories defined by Lloyd \& Helmer [28], finished water E. coli levels could be considered to be of "very low" ( $<1 \mathrm{MPN} / 100 \mathrm{~mL}$ ) or "low" risk (1 to $10 \mathrm{MPN} / 100 \mathrm{~mL}$ ). It is worth noting that such laboratory efficacy results may differ from performance in the field due to a variety of factors (i.e., end-user training/habits, implementation strategy, variable water quality, etc.). Such differences (i.e., laboratory versus field performance) have been observed previously with CDPs $[25,26,29]$ and other POU water treatment techniques [30-32].

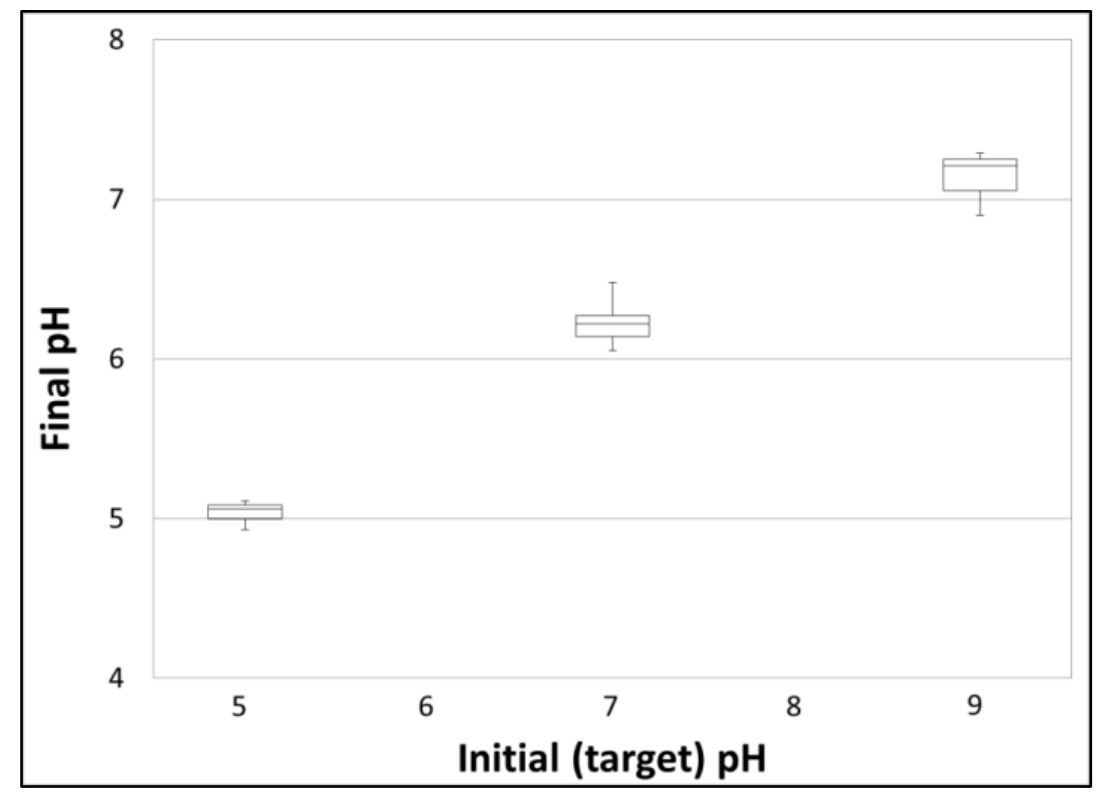

Figure 4. Box-and-whisker plots (min/max, lower/upper quartiles, and median) of the final treatment $\mathrm{pHs}$ for each initial target $\mathrm{pH}$ tested.

The turbidity reductions (Figure 5) of test series A to E with initial turbidity levels varying between 100 and 800 NTU were similar to those of previous studies in similar test conditions [9,15]. Although final turbidity levels were mostly within 5 and $10 \mathrm{NTU}$, these may not necessarily be correlated with the visual acceptability of the finished water by potential users. Tests series F and G on natural surface waters had relatively low initial turbidity and resulted in higher final turbidity levels (Table 3). Such increases have been observed elsewhere in low initial turbidity conditions [12]. Relatively low turbidity reductions may also be due to the use of a relatively thin porous cloth (intended to simulate challenging conditions). Use of thicker filtration materials can improve such reductions [9], but can also increase the treatment time, which could be a deterrent to the sustained use of POU interventions [33]. 


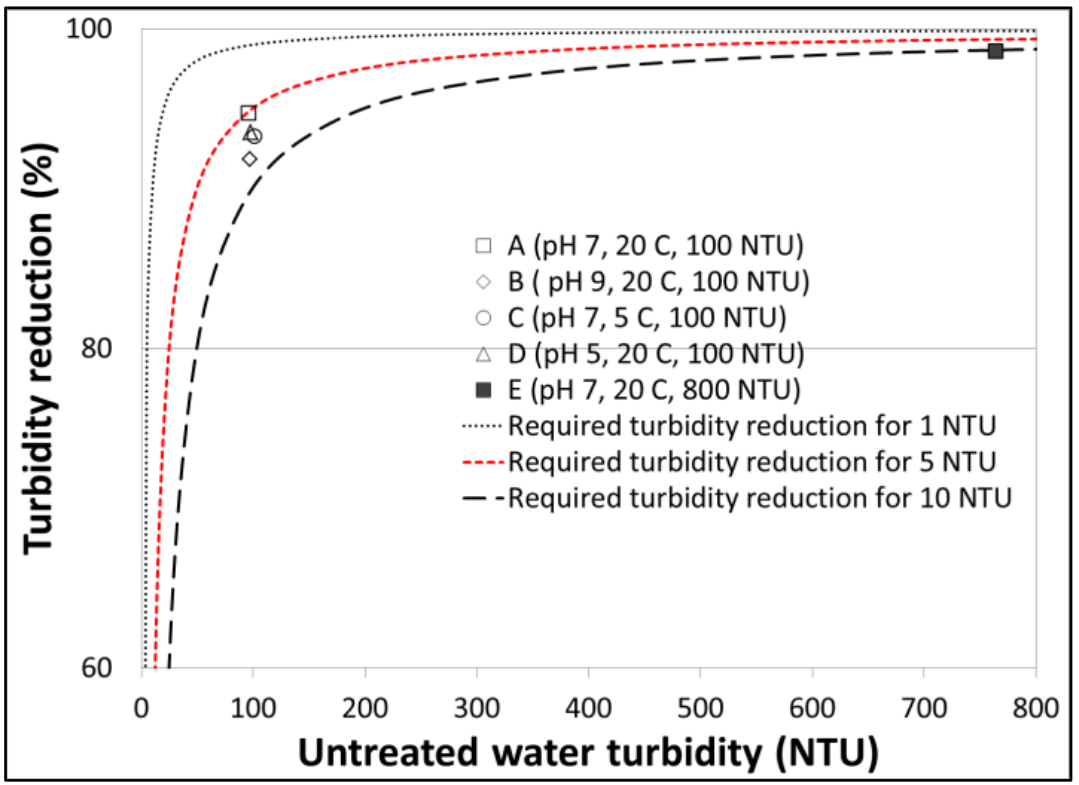

Figure 5. Average treated water turbidity reductions for test series A-E with required turbidity reductions to achieve specified treatment targets.

Overall, the performance of the AQS with regard to FCR levels after treatment (60 min after addition) and after $24 \mathrm{~h}$ was poor. Apart from the trials on demand free water (DW-series H), average FCR concentrations above $0.5 \mathrm{mg} / \mathrm{L}$ were only achieved in test series F with the SW-Low test water matrix (St. Lawrence River with a relatively low average TOC of $4 \mathrm{mg} / \mathrm{L}$ ). Other CDPs tested in similar conditions with a PSWd test water matrix also did not achieve $0.5 \mathrm{mg} / \mathrm{L} \mathrm{FCR}$ after treatment $[9,15]$. In tests with natural surface and synthetic test waters, the AQS tablet had a relatively worse performance in comparison to the product tested by Marois-Fiset et al. [9]. However, that product only achieved the target FCR after $24 \mathrm{~h}$ of simulated storage when tested with DW test water. These results suggest that AQS tablet formulation may warrant improvement. According to the manufacturers, the tested version had a "slow release" NADCC disinfectant. The NADCC release kinetics were not measured, but it is possible that any disinfectant that had not been totally dissolved was filtered out once the settling period was over. It is also possible that the initial FCR levels were not sufficient to overcome the chlorine demand of the natural surface waters tested. Based on these results with the tested product formulation, it is possible that this product may not attain recommended FCR levels (after $30 \mathrm{~min}$ and $24 \mathrm{~h}$ ) in field conditions.

Notably, the THM levels resulting from the lower TOC test water (SW-Low) resulted in relatively higher DBP levels in comparison to the SW-High2 (i.e., Marais du Nord) test water for which higher THM levels were expected. Although the testing design considered organic content based on an aggregate parameter (i.e., TOC), it did not consider the possible differences resulting from the organic fractionation of the surface waters tested. This may explain the higher THM values in waters with lower TOC content. It seems that the formulation of the batch used for the DBP tests differed from the one used in the treatment performance trials. Target FCR levels (at 0.5 and $24 \mathrm{~h}$ ) were achieved in all waters tested (Figure 3). As such, it is possible that higher bacterial LRs could have been observed if this parameter had been tested for in these trials. The $\mathrm{pH}$ values of test waters in DBP trials were in the neutral to mildly acidic range (Figure 3). The addition of the AQS resulted in a slightly reduced $\mathrm{pH}$ after $2 \mathrm{~h}$, which tended to increase back towards original values after $24 \mathrm{~h}$. Lower $\mathrm{pH}$ values typically result in lower THM concentrations and increased HAA concentrations [34]. This may also have explained why test water SW-Low (with higher $\mathrm{pH}$ ) resulted in higher THM concentrations than the SW-High2 test water. 
The total THM values after $24 \mathrm{~h}$ of CDP dosing in the present study varied between 0.027 and $0.056 \mathrm{mg} / \mathrm{L}$. Lantagne et al. [11] found that total THM concentrations after $24 \mathrm{~h}$ varied between $<0.05$ to between $0.020-0.025 \mathrm{mg} / \mathrm{L}$. In another study [12], this range was of approximately $0.020-0.110 \mathrm{mg} / \mathrm{L}$. However, given the variability of water sources, water treatment products evaluated, and test conditions, a direct comparison between studies is perhaps not meaningful. To achieve this, a direct comparison between products would need to be done under similar conditions. This could also highlight any potential advantages between products with regard to their formulation (i.e., calcium hypochlorite versus NADCC) and benefits in terms of improved FCR levels and reduced DBP formation, as has been speculated elsewhere [10]. However, general trends of increasing THM formation with time are in accordance with the literature. Chloroform (TCM) was the main THM species formed in accordance with other studies considering DBP formation following use of CDPs $[11,12]$. Furthermore, these studies have also demonstrated that CDPs result in fewer DBPs after treatment when compared to chlorination alone. It is highly plausible that the CDP tested in this study would present such an advantage with regard to DBP formation. Other studies have not considered HAA formation from chlorine-based POU water treatment interventions in similar contexts. Given that this type of product is intended to be the sole form of treatment (i.e., no pre-treatment), it is difficult to operationally mitigate DBP formation considering that the coagulant and disinfectant are added at the same time. Further research could elucidate whether changes to CDP formulation could result in better DBP precursor removal and reduced overall DBP formation.

For the tested conditions in this study, both families of DBPs were below the USEPA [21] maximum contaminant limits for THMs $(0.080 \mathrm{mg} / \mathrm{L})$ and HAAs $(0.060 \mathrm{mg} / \mathrm{L})$. THMs observed in this study were below the WHO [16] additive toxicity guideline value (i.e., the sum of the actual values of the four THMs divided by their respective guideline values should be less than 1). It is worth noting that such regulatory and guideline values are based on chronic health risks assuming exposure periods that are longer than the intended use of CDPs, such as the one evaluated here. It would be perhaps more relevant to consider DBP-related health risks of CDPs from a sub-chronic exposure perspective (i.e., with exposure between 30 days to a year). However, sub-chronic exposure risks of DBPs are not as well characterized nor as well regulated. There is emerging but limited literature on the sub-chronic toxicity of DBPs [35-37], and further research is necessary to characterize the risks and to determine health-based guidance values. This could help better inform relevant guidelines for humanitarian contexts [17], which preconize that short-term use of chemical contaminants (interpreted here to include DBPs from the use of disinfectants) and assessments show no significant probability of negative health effects. However, any such guidelines should be formulated in light of the primary objective of CDPs, which is the production of drinking water that is microbially safe.

\section{Conclusions}

The tests conducted in this study have served to elucidate the performance envelopes of the AQS $10 \mathrm{~L}$ tablet tested under challenging conditions. The CDP was capable of $E$. coli $\log _{10}$ reductions of at least 4, resulting in a "highly protective" status. The majority of the treated water samples had no detectable E. coli, and all were consistently below $10 \mathrm{MPN} / 100 \mathrm{~mL}$. For most conditions, target FCR values were not attained. Treated water turbidity levels were mostly between the non-health-based targets of 5 NTU and 10 NTU. THM and HAA levels were below the regulatory and health-based targets for both families of DBPs studied.

Author Contributions: Conceptualization, C.C.D.; Methodology, F.L.-J., C.B. and C.C.D.; Validation, F.L.-J. and C.C.D.; Formal Analysis, F.L.-J. and C.C.D.; Investigation, F.L.-J., O.L. and U.V.-G.; Data Curation, F.L.-J. and C.C.D.; Writing-Original Draft Preparation, C.C.D.; Writing-Review \& Editing, C.C.D.; Supervision, C.B. and C.C.D.; Project Administration, C.C.D.; Funding Acquisition, C.C.D.

Funding: This research was partially funded by Aquasure S.A.S. (grant number SIRUL/106819). FLJ, OL, and UVG were partially supported by scholarship funds from the Natural Sciences and Engineering Research Council and the Ministère de l'Éducation, du Loisir et du Sport. CCD was partially supported by CNPq (grant number 400576/2013-9). 
Acknowledgments: Michel Bisping is acknowledged for the training and technical support given to FLJ, OL, and UVG. Sabrina Simard and Manuel Rodriguez (NSERC Industrial Research Chair in Monitoring and Management of Drinking Water Quality from Source to Consumer) are thanked for their support regarding DBP analyses.

Conflicts of Interest: The authors declare no conflict of interest. However, we note that this study was partially supported with a grant for the independent evaluation of the product that was also supplied by Aquasure S.A.S. Aquasure S.A.S. was initially consulted regarding product characteristics. Otherwise, funders had no role in the design of the study; in the collection, analyses, or interpretation of data; in the writing of the manuscript, or in the decision to publish the results.

\section{References}

1. Clasen, T.; Schmidt, W.-P.; Rabie, T.; Roberts, I.; Cairncross, S. Interventions to improve water quality for preventing diarrhoea: Systematic review and meta-analysis. BMJ 2007, 334, 782. [CrossRef] [PubMed]

2. Onda, K.; LoBuglio, J.; Bartram, J. Global Access to Safe Water: Accounting for Water Quality and the Resulting Impact on MDG Progress. World Health Popul. 2013, 14, 32-44. [CrossRef] [PubMed]

3. Lantagne, D.S.; Clasen, T.F. Use of Household Water Treatment and Safe Storage Methods in Acute Emergency Response: Case Study Results from Nepal, Indonesia, Kenya, and Haiti. Environ. Sci. Technol. 2012, 46, 11352-11360. [CrossRef] [PubMed]

4. Brown, J.; Cavill, S.; Cumming, O.; Jeandron, A. Water, sanitation, and hygiene in emergencies: Summary review and recommendations for further research. Waterlines 2012, 31, 11-29. [CrossRef]

5. Crump, J.A.; Otieno, P.O.; Slutsker, L.; Keswick, B.H.; Rosen, D.H.; Hoekstra, R.M.; Vulule, J.M.; Luby, S.P. Household based treatment of drinking water with flocculant-disinfectant for preventing diarrhoea in areas with turbid source water in rural western Kenya: Cluster randomised controlled trial. BMJ 2005, 331, 478. [CrossRef] [PubMed]

6. Chiller, T.M.; Mendoza, C.E.; Lopez, M.B.; Alvarez, M.; Hoekstra, R.M.; Keswick, B.H.; Luby, S.P. Reducing diarrhoea in Guatemalan children: Randomized controlled trial of flocculant-disinfectant for drinking-water. Bull. World Health Organ. 2006, 84, 28-35. [CrossRef] [PubMed]

7. Doocy, S.; Burnham, G. Point-of-use water treatment and diarrhoea reduction in the emergency context: An effectiveness trial in Liberia. Trop. Med. Int. Health 2006, 11, 1542-1552. [CrossRef] [PubMed]

8. Colindres, R.E.; Jain, S.; Bowen, A.; Mintz, E.; Domond, P. After the flood: An evaluation of in-home drinking water treatment with combined flocculent-disinfectant following Tropical Storm Jeanne-Gonaives, Haiti, 2004. J. Water Health 2007, 5, 367-374. [CrossRef] [PubMed]

9. Marois-Fiset, J.-T.; Shaheed, A.; Brown, J.; Dorea, C.C. Laboratory evaluation of a new coagulant/disinfectant point-of-use water treatment product for emergencies. J. Appl. Microbiol. 2016, 121, 892-902. [CrossRef] [PubMed]

10. Clasen, T.; Edmondson, P. Sodium dichloroisocyanurate (NaDCC) tablets as an alternative to sodium hypochlorite for the routine treatment of drinking water at the household level. Int. J. Hyg. Environ. Health 2006, 209, 173-181. [CrossRef] [PubMed]

11. Lantagne, D.S.; Blount, B.C.; Cardinali, F.; Quick, R. Disinfection by-product formation and mitigation strategies in point-of-use chlorination of turbid and non-turbid waters in western Kenya. J. Water Health 2008, 6, 67-82. [CrossRef] [PubMed]

12. Lantagne, D.S.; Cardinali, F.; Blount, B.C. Disinfection By-Product Formation and Mitigation Strategies in Point-of-Use Chlorination with Sodium Dichloroisocyanurate in Tanzania. Am. J. Trop. Med. Hyg. 2010, 83, 135-143. [CrossRef] [PubMed]

13. Smith, E.M.; Plewa, M.J.; Lindell, C.L.; Richardson, S.D.; Mitch, W.A. Comparison of Byproduct Formation in Waters Treated with Chlorine and Iodine: Relevance to Point-of-Use Treatment. Environ. Sci. Technol. 2010, 44, 8446-8452. [CrossRef] [PubMed]

14. Werner, D.; Valdivia-Garcia, M.; Weir, P.; Haffey, M. Trihalomethanes formation in point of use surface water disinfection with chlorine or chlorine dioxide tablets. Water Environ. J. 2016, 30, 271-277. [CrossRef]

15. Marois-Fiset, J.-T.; Carabin, A.; Lavoie, A.; Dorea, C.C. Effects of Temperature and pH on Reduction of Bacteria in a Point-of-Use Drinking Water Treatment Product for Emergency Relief. Appl. Environ. Microbiol. 2013, 79, 2107-2109. [CrossRef] [PubMed] 
16. WHO. Guidelines for Drinking-Water Quality, 4th ed.; World Health Organization: Geneva, Switzerland, 2011; ISBN 978-92-4-154815-1.

17. The Sphere Project. Humanitarian Charter and Minimum Standards in Humanitarian Response, 3rd ed.; The Sphere Project: Rugby, UK, 2011.

18. WHO. Evaluating Household Water Treatment Options: Health-Based Targets and Microbiological Performance Specifications; World Health Organization: Geneva, Switzerland, 2011; ISBN 978-92-4-154822-9.

19. Lantagne, D.S. Sodium hypochlorite dosage for household and emergency water treatment. J. Am. Water Works Assoc. 2008, 100, 106-119. [CrossRef]

20. CDC. Free Chlorine Testing. Available online: http://http://www.cdc.gov/safewater/chlorine-residualtesting.html (accessed on 30 January 2013).

21. USEPA. Comprehensive Disinfectants and Disinfection Byproducts Rules (Stage 1 and Stage 2): Quick Reference Guide; United States Environmental Protection Agency: Washington, DC, USA, 2010.

22. Eloidin, O.; Dorea, C.C. Evaluation of semidecentralized emergency drinking water treatment. J. Environ. Sci. Health Part A 2015, 50, 1040-1045. [CrossRef] [PubMed]

23. Légaré-Julien, F. Formation des Sous-Produits de Désinfection par Différents Traitements à Base de Chlore Conçus Pour Traiter L'eau Potable à Domicile. Master's Thesis, Université Laval, Québec, QC, Canada, 2017.

24. Mercier Shanks, C.; Sérodes, J.-B.; Rodriguez, M.J. Spatio-temporal variability of non-regulated disinfection by-products within a drinking water distribution network. Water Res. 2013, 47, 3231-3243. [CrossRef] [PubMed]

25. Crump, J.A.; Okoth, G.O.; Slutsker, L.; Ogaja, D.O.; Keswick, B.H.; Luby, S.P. Effect of point-of-use disinfection, flocculation and combined flocculation-disinfection on drinking water quality in western Kenya. J. Appl. Microbiol. 2004, 97, 225-231. [CrossRef] [PubMed]

26. Souter, P.F.; Cruickshank, G.D.; Tankerville, M.Z.; Keswick, B.H.; Ellis, B.D.; Langworthy, D.E.; Metz, K.A.; Appleby, M.R.; Hamilton, N.; Jones, A.L.; et al. Evaluation of a new water treatment for point-of-use household applications to remove microorganisms and arsenic from drinking water. J. Water Health 2003, 1, 73-84. [CrossRef] [PubMed]

27. McLennan, S.D.; Peterson, L.A.; Rose, J.B. Comparison of Point-of-Use Technologies for Emergency Disinfection of Sewage-Contaminated Drinking Water. Appl. Environ. Microbiol. 2009, 75, 7283-7286. [CrossRef] [PubMed]

28. Lloyd, B.; Helmer, R. Surveillance of Drinking Water Quality in Rural Areas; John Wiley \& Sons: New York, NY, USA, 1991.

29. Rangel, J.M.; Lopez, B.; Mejia, M.A.; Mendoza, C.; Luby, S. A novel technology to improve drinking water quality: A microbiological evaluation of in-home flocculation and chlorination in rural Guatemala. J. Water Health 2003, 1 , 15-22. [CrossRef] [PubMed]

30. Stauber, C.E.; Elliott, M.A.; Koksal, F.; Ortiz, G.M.; DiGiano, F.A.; Sobsey, M.D. Characterisation of the biosand filter for E. coli reductions from household drinking water under controlled laboratory and field use conditions. Water Sci. Technol. 2006, 54, 1-7. [CrossRef] [PubMed]

31. Levy, K.; Anderson, L.; Robb, K.A.; Cevallos, W.; Trueba, G.; Eisenberg, J.N.S. Household effectiveness vs. laboratory efficacy of point-of-use chlorination. Water Res. 2014, 54, 69-77. [CrossRef] [PubMed]

32. Murray, A.L.; Stewart, B.; Hopper, C.; Tobin, E.; Rivera, J.; Mut-Tracy, H.; Stewart, P.; Stewart, C.; Tobin, C.; Goeb, M.; et al. Laboratory efficacy and field effectiveness of hollow fiber membrane microfilters used for household water treatment in Honduras. J. Water Sanit. Hyg. Dev. 2017, 7, 74-84. [CrossRef]

33. Luoto, J.; Najnin, N.; Mahmud, M.; Albert, J.; Islam, M.S.; Luby, S.; Unicomb, L.; Levine, D.I. What Point-of-Use Water Treatment Products Do Consumers Use? Evidence from a Randomized Controlled Trial among the Urban Poor in Bangladesh. PLoS ONE 2011, 6, e26132. [CrossRef] [PubMed]

34. Crittenden, J.C.; Trussell, R.R.; Hand, D.W.; Howe, K.J.; Tchobanoglous, G. MWH's Water Treatment: Principles and Design, 3rd ed.; John Wiley \& Sons: Hoboken, NJ, USA, 2012; ISBN 978-0-470-40539-0.

35. Weber, N.M.; Sawyer, H.R.; Legare, M.E.; Veeramachaneni, D.N.R. Sub-chronic Exposure to Dibromoacetic Acid, a Water Disinfection By-product, Does Not Affect Gametogenic Potential in Mice. Toxicol. Sci. 2006, 89, 325-330. [CrossRef] [PubMed] 
36. Florentin, A.; Hautemanière, A.; Hartemann, P. Health effects of disinfection by-products in chlorinated swimming pools. Int. J. Hyg. Environ. Health 2011, 214, 461-469. [CrossRef] [PubMed]

37. Rice, G.; MacDonell, M.; Hertzberg, R.C.; Teuschler, L.; Picel, K.; Butler, J.; Chang, Y.-S.; Hartmann, H. An approach for assessing human exposures to chemical mixtures in the environment. Toxicol. Appl. Pharmacol. 2008, 233, 126-136. [CrossRef] [PubMed] 